\title{
Nachweise der Motti in Vorspann und Vorwort
}

Der Ausspruch von Döblin findet sich z. B. in: Alfred Döblin, Kleine Schriften, Olten und Freiburg (Walter) 1985, Band 1, Seite 150. Döblin war zynisch.

Der Ausspruch von Goethe findet sich z. B. in: Johann Wolfgang Goethe, Gedenkausgabe hg. v. Ernst Beutler, Zürich (Artemis) $1948 \mathrm{ff} .$, Band 23 (Gespräche, Teil 2), S. 596. Goethe war ehrlich.

Der Ausspruch von Byron ist zugleich der Titel des gleichnamigen Buches des amerikanischen Großverlegers William (»Bill») Jovanovich (s. Bibliographie und a.a.O. Seite 21). Lord Byron war der Begründer des »Byronismus «. 